\title{
Christian nominality in methodism
}

\author{
A Bester* \\ (University of Pretoria)
}

\section{ABSTRACT}

\section{Christian nominality in methodism}

The paper explores "discipleship" in the discipline of "Building up the local church". The empirical research indicates a perceived difference in what it means to be a disciple and what it means to be a Christian with the increasing belief that discipleship is an optional extra to the Christian calling and even a "higher form" of Christian development. The causes of nominal Christianity within Methodism and how this has resulted in a misunderstanding of true discipleship are considered. The paper opens a way forward for the local church to overcome nominal Christianity and to enable the process of making disciples and practising discipleship.

\section{INTRODUCTION}

It is observed that many Christians feel that to be a "disciple of Christ" means being something more than "Christian". This study seeks to understand the different popular definitions of "Christian" and "disciple" so as to determine the causes of nominal Christianity which may assist in the process of overcoming nominal Christianity and assist in the process of discipleship.

It is affirmed that neither the teachings or practices of Jesus, nor that of the early church, ever intended a different understanding between a disciple and a Christian: "every Christian is a disciple" (Nel 1990:41). Christian discipleship, evident from the relationship between Jesus and his disciples, bears the following marks: the answering of a call extended by Jesus (cf Mt 4:18-22; Mk 1:16-20; Lk 5:1-11); the call to follow the person of Jesus and to surrender oneself completely to him (Bonhoeffer 1988:52; Peterson 1997: 12); the call to be and remain an obedient learner of Jesus (Bosch 1991:37) in the company of the fellow disciples (Watson 1983:35) where Jesus is the content and the focus of the learning (Bosch 1991:37); and, the call to be the faithful witness of Jesus (Bosch 1991:38).

* A Bester is a Masters student in the Department of Practical Theology under the supervision of Prof M Nel and Prof C J A Vos. 
In the period of Jesus' earthly ministry and the period of the early church the two terms "Christian" and "disciple" may be considered synonymous. Jesus never referred to His followers as Christians and only in Acts 11:26 do we read that "it was in Antioch that the disciples were first called "Christians" (NRSV). It is deduced that "Christian" is the title given to the disciples who followed the Christ. However, through the course of Church history, and in particular from the time of the postConstantine society onwards, the popular thought that discipleship as something extra and optional to the call to be Christian became an accepted norm (Shelley 1982:133).

To test this observation a group within the context of the local congregation was selected and in the form of a preliminary questionnaire, the following open questions were asked: What is your definition of a Christian? What is your definition of a disciple? Is there a difference between a Christian and a disciple?

While the majority clearly indicated, in answering the latter question, that there is no major difference between a Christian and a disciple (of Christ), each questionnaire, with the exception of one, gave a different definition of a "Christian" and of a "disciple". There seemed to be the clear understanding, or rather misunderstanding, that to be Christian implied believing, while being a disciple implied doing.

Through further empirical study the following questions need to be asked: If Christians believe that all Christians should be disciples, why is there the perception that not all Christians are disciples? Has "nominal christianity" become an accepted form of Christian calling in which discipleship is an optional or higher form of calling? What factors will lead to rediscovering a correct understanding of Christian calling and discipleship?

The study is limited to the Methodist tradition and within a South African suburban community. Furthermore, while not ideal according to the Methodist's church's statement of being "one indivisible fellowship" (Methodist Church of Southern Africa 2000:1) the study focuses largely on the local church which has a predominantly white membership.

\section{METHODIST PERSPECTIVE OF DISCIPLESHIP}

The introduction of the Methodist Church's Laws and Discipline (2000:1) reads: 
"The Church is the company of disciples of Jesus ... These constitute the family of the redeemed children of God, who in the New Testament are described as 'believers', 'People of God', and 'Christians'” [Emphasis mine].

In Methodism there can be no distinction between being Christian and being a disciple. Wesley (2000c) considers the moment of salvation (i.e. becoming a Christian) and the process of discipleship (sanctification) as a natural working out of our salvation. In other words the ultimate purpose of our salvation (being Christian) is our faithful discipleship. Failing to understand this frustrates the very cause of the Christ in his desire to minister through us as his disciples. Yet, the problem exists that there is a difference of definition in practice of what it means to be a disciple and what it means to be a Christian.

To analyse the understanding of "being Christian" and "discipleship" within Southern African Methodism an empirical study has been conducted. A total of 162 members of the Methodist Church completed the questionnaire (cf. Table 1). 74 (46\%) are members of the local church (Glen Methodist Church, Garsfontein), 49 (30\%) are representatives of the Limpopo district (the former Northern Transvaal and Botswana), and 39 $(24 \%)$ are students at the Methodist training institution, John Wesley College, Pretoria.

\subsection{Understanding the concepts “Christian" and "disciple”}

In the open-ended definition questions (Table 1) 57\% of all who participated in the survey indicated that there was a difference in definition between a disciple and a Christian. Among the clergy $47 \%$ indicated a difference of definition and among the laity, $66 \%$. 


\section{Table 1: Analysis of data - Understanding the concepts "Christian" and "disciple"}

OP1, OP2, OP3 - Members were asked in an open question format their definition of a Christian and of a disciple, and to note, if any, any differences.

Key: OP1: Members who indicated that there is no difference between a disciple and a Christian.

OP2: Members who indicated that there should be no difference between a disciple and a Christian.

OP3: Members who indicated that there is a difference between a disciple and a Christian.

Q1: Members who agreed with the statement "A Christian is a disciple"

Q2: Members who agreed with the statement "All Christians should be disciples"

Q3: Members who agreed with the statement "You don't have to be a disciple to be a Christian"

Q4: Members who agreed with the statement "A call to be a disciple is an additional call to be a Christian"

Greyed out squares indicate more than a 10\% variance from the total Questionnaire average.

\begin{tabular}{|c|c|c|c|c|c|c|c|c|c|c|c|c|c|c|c|}
\hline Category & Total & OP1 & $\%$ & OP2 & $\%$ & OP3 & $\%$ & Q1 & $\%$ & Q2 & $\%$ & Q3 & $\%$ & Q4 & $\%$ \\
\hline All Questionnaires & 162 & 43 & $27 \%$ & 27 & $17 \%$ & 92 & $57 \%$ & 107 & $66 \%$ & 132 & $81 \%$ & 69 & $43 \%$ & 88 & $54 \%$ \\
\hline $\begin{array}{l}\text { Glen Methodist } \\
\text { Members }\end{array}$ & 74 & 18 & $24 \%$ & 10 & $14 \%$ & 49 & $66 \%$ & 46 & $62 \%$ & 57 & $77 \%$ & 36 & $49 \%$ & 41 & $55 \%$ \\
\hline District Representatives & 49 & 10 & $20 \%$ & 12 & $24 \%$ & 27 & $55 \%$ & 33 & $67 \%$ & 43 & $88 \%$ & 17 & $35 \%$ & 21 & $42 \%$ \\
\hline $\begin{array}{l}\text { Students at John } \\
\text { Wesley College }\end{array}$ & 39 & 15 & $38 \%$ & 5 & $13 \%$ & 19 & $49 \%$ & 28 & $72 \%$ & 32 & $82 \%$ & 16 & $41 \%$ & 26 & $38 \%$ \\
\hline Lay Person & 117 & 33 & $28 \%$ & 13 & $11 \%$ & 77 & $66 \%$ & 76 & $65 \%$ & 89 & $76 \%$ & 55 & $47 \%$ & 69 & $59 \%$ \\
\hline Clergy Person & 45 & 10 & $22 \%$ & 14 & $31 \%$ & 21 & $47 \%$ & 31 & $69 \%$ & 43 & $96 \%$ & 14 & $31 \%$ & 19 & $42 \%$ \\
\hline Female & 76 & 21 & $28 \%$ & 13 & $17 \%$ & 42 & $55 \%$ & 47 & $62 \%$ & 58 & $76 \%$ & 31 & $41 \%$ & 43 & $57 \%$ \\
\hline Male & 83 & 20 & $24 \%$ & 14 & $17 \%$ & 49 & $59 \%$ & 57 & $69 \%$ & 71 & $86 \%$ & 37 & $45 \%$ & 43 & $52 \%$ \\
\hline Under 20 Years & 19 & 7 & $37 \%$ & 2 & $11 \%$ & 10 & $53 \%$ & 10 & $53 \%$ & 7 & $37 \%$ & 14 & $73 \%$ & 9 & $47 \%$ \\
\hline $20-29$ years & 29 & 10 & $34 \%$ & 4 & $14 \%$ & 15 & $52 \%$ & 24 & $84 \%$ & 24 & $83 \%$ & 10 & $34 \%$ & 18 & $62 \%$ \\
\hline $30-39$ years & 33 & 7 & $21 \%$ & 5 & $15 \%$ & 21 & $64 \%$ & 17 & $52 \%$ & 28 & $85 \%$ & 14 & $42 \%$ & 18 & $55 \%$ \\
\hline $40-49$ years & 30 & 7 & $23 \%$ & 9 & $30 \%$ & 14 & $47 \%$ & 22 & $73 \%$ & 28 & $93 \%$ & 9 & $30 \%$ & 11 & $37 \%$ \\
\hline $50-59$ years & 22 & 4 & $18 \%$ & 3 & $14 \%$ & 15 & $68 \%$ & 14 & $64 \%$ & 17 & $77 \%$ & 11 & $50 \%$ & 13 & $59 \%$ \\
\hline $60+$ years & 29 & 8 & $28 \%$ & 4 & $14 \%$ & 17 & $59 \%$ & 20 & $69 \%$ & 28 & $97 \%$ & 11 & $38 \%$ & 19 & $66 \%$ \\
\hline $\begin{array}{l}\text { District Reps from black } \\
\text { churches }\end{array}$ & 18 & 6 & $33 \%$ & 2 & $11 \%$ & 10 & $56 \%$ & 15 & $83 \%$ & 15 & $83 \%$ & 7 & $39 \%$ & 12 & $67 \%$ \\
\hline $\begin{array}{l}\text { District Reps from white } \\
\text { churches }\end{array}$ & 30 & 4 & $13 \%$ & 10 & $33 \%$ & 16 & $53 \%$ & 18 & $60 \%$ & 28 & $93 \%$ & 9 & $30 \%$ & 9 & $30 \%$ \\
\hline Small group members & 136 & 36 & $27 \%$ & 24 & $18 \%$ & 76 & $56 \%$ & 89 & $65 \%$ & 112 & $83 \%$ & 58 & $43 \%$ & 73 & $54 \%$ \\
\hline Small group leaders & 60 & 16 & $27 \%$ & 16 & $27 \%$ & 28 & $47 \%$ & 40 & $67 \%$ & 54 & $90 \%$ & 22 & $37 \%$ & 28 & $47 \%$ \\
\hline
\end{tabular}

The majority of replies where a difference in definition was indicated said that a Christian could be understood as one who "believes" whereas a disciple may be understood as one who "follows", "serves" and "spreads the gospel".

Of all the questionnaires completed where members were asked to agree or disagree to certain statements, $81 \%$ indicated that all Christians should be disciples. $43 \%$ indicated that you don't have to be a disciple to 
be a Christian. $54 \%$ indicated that to be a disciple is an additional call to being Christian.

What is especially noticeable is the considerable variance in certain categories. The students at John Wesley College had a remarkable lower percentage of $38 \%$ who indicated that the call to be a disciple is in addition to the call of being Christian. This is in contrast to the average of $54 \%$. I would surmise that this in line with the teaching material on discipleship. This interestingly compares to a figure of $42 \%$ for clergy which while still significantly lower than the general average is slightly above that of the students.

The breakdown in age groups gives some interesting results. The most notable is in the age group of under 20 years. Among these teenagers, only $37 \%$ indicated that all Christians should be disciples as opposed to a general average of $81 \%$. This is also significantly different from the age group 60 and over of which 97\% indicate that all Christians should be disciples. Again among the teenagers there are $73 \%$ who indicate that you don't have to be a disciple to be a Christian against the general average of $43 \%$ and the $38 \%$ of the 60 years and older. The data indicates that with increasing age there is a growing awareness of what it means to be a disciple. Not included in the questionnaire is to determine how long a member has been a Christian. This would help clarify whether the questions differed only as a result of age, or perhaps as a result of the duration of time being a Christian. Alternatively, the data could also indicate that the youth do not feel part of the church and its teaching.

While there were not a large number of questionnaires completed by district representatives there is significant variance in the results for a brief mention. $67 \%$ of predominately black church members indicated that the call to discipleship is an additional call to being Christian, as opposed to the $30 \%$ of predominantly white churches. The differences in leadership style, worship, preaching, etc. may all contribute to these variances in categories.

It is unfortunately not in the scope of this article to consider in depth the causes of the variances between the categories, but it does highlight the research problem that in general there is the acceptance that while all Christians should be disciples, not all are, and that to be a disciple is an additional call to being a Christian. 


\subsection{Defining the marks of a Christian and the marks of a disciple}

The questionnaire also sought to determine what constitutes a "Christian" and a "disciple". Five marks of Christian discipleship were summarised from the Methodist Church's Laws and Discipline (2000:14-16), that is, a Christian disciple is someone (1) who is committed to Jesus Christ as Lord and Saviour; (2) who worships regularly; (3) who fellowships regularly; (4) who gives generously; and (5) who serves. Members were asked which marks are associated with a Christian and which with a disciple. Considering the thesis that Christians and disciples are one and the same, one would expect that members to have identical results for both marks of a "Christian" and marks of a "disciple".

$48 \%$ of members indicated that Christians and disciples all share the same 5 marks. 58\%, irrespective of the number of marks ticked, indicated that Christians and disciples shared the same characteristics. This means that $42 \%$ indicated that the marks of being Christian and of being a disciple were different.

\section{Table 2: Analysis of data - Marks of a "Christian" and a "disciple”}

The following marks are summarised from the Methodist Church's Laws and discipline (2000:14-16) which lists the conditions of membership, the Methodist ethos, the Christian community and the Methodist rule of life.

Key: C: Who is committed to Jesus Christ as Lord and Saviour

W: Who worships regularly

F: Who fellowships regularly

G: Who gives generously

S: Who serves

Members were ask to indicate which of the above characteristics they considered to be marks of a Christian:

\begin{tabular}{|l|l||l|l||l|l||l|l||l|l||l|l|}
\hline Category & Total & C & $\%$ & W & $\%$ & F & $\%$ & G & $\%$ & S & $\%$ \\
\hline All Questionnaires & 162 & 157 & $97 \%$ & 117 & $72 \%$ & 113 & $70 \%$ & 105 & $65 \%$ & 125 & $77 \%$ \\
\hline Under 40 Years & 81 & 80 & $99 \%$ & 51 & $63 \%$ & 48 & $59 \%$ & 45 & $56 \%$ & 57 & $70 \%$ \\
\hline 40 Years and over & 81 & 77 & $95 \%$ & 66 & $81 \%$ & 65 & $80 \%$ & 60 & $74 \%$ & 68 & $84 \%$ \\
\hline
\end{tabular}

Members were ask to indicate which of the above characteristics they considered to be marks of a Disciple:

\begin{tabular}{|l|l||l|l|l|l|l|l||l|l||l|l|}
\hline Category & Total & C & $\%$ & W & $\%$ & F & $\%$ & G & $\%$ & S & $\%$ \\
\hline All Questionnaires & 162 & 149 & $92 \%$ & 116 & $72 \%$ & 127 & $78 \%$ & 113 & $70 \%$ & 148 & $91 \%$ \\
\hline Under 40 Years & 81 & 71 & $88 \%$ & 55 & $68 \%$ & 63 & $78 \%$ & 53 & $65 \%$ & 75 & $93 \%$ \\
\hline 40 Years and over & 81 & 78 & $93 \%$ & 61 & $75 \%$ & 64 & $79 \%$ & 60 & $74 \%$ & 73 & $90 \%$ \\
\hline
\end{tabular}


The prominent perceived difference (Table 2) between that of a Christian and a disciple is the mark of service. While $77 \%$ indicated that "to serve" was a mark of a Christian, $91 \%$ indicated that it was a mark of a disciple.

It is important to note the different perspectives as to the marks of a Christian according to age. Apart from the commitment to Jesus Christ each of the remaining marks is considerably lower for those under 40. In regards of giving one has to note the financial strains on young members, and as regards fellowship, worship and service, the demands of family life. Yet, it is concerning that these should influence the understanding or expectation of what it means to be Christian. It may also mean, for example in the fellowship opportunities for young couples with children, that churches are not providing adequate small groups that meet the needs of such members, and hence the perception of what it means to be a Christian.

These findings support the research problem that there exists with the Methodist church a differing interpretation of what it means to be a disciple and what it means to be a Christian. The problem is intensified when one considers that more than half of the local church considers discipleship as an additional call to being a Christian and just under half believe that you don't have to be a disciple to be a Christian.

In response to the research problem it is necessary to consider within the Methodist Church what factors have contributed to the loss of the meaning of discipleship that may assist the local church to overcome nominal Christianity and assist the process of making and building disciples.

\section{NOMINALITY - A METHODIST PERSPECTIVE}

From a Methodist perspective the causes leading to nominality may be deduced from Wesley's teaching that nominality is the result of members not utilising the means of grace (Wesley 2000a). Williams (1988:130) comments:

"Wesley was convinced that fallen man, lifted up by God's grace, can remain in that grace only when he seeks to use it in obedience to God's commandments. He was further convinced that we can grow in grace only by constant attendance upon the means of grace, and that the neglect of these leads to that falling away which is the occasion of sin". 
Wesley (2000b) writes:

"It is therefore expected of all who continue therein, that they should continue to evidence their desire of salvation" by "doing no harm" and "by avoiding evil", "by doing good", and by "attending upon all the ordnances of God" [the means of grace].

These means of grace are then the means of being disciples of Christ, of nurturing the process of discipleship, and by not utilising them Christians are at the risk being nominal.

\subsection{Analysis of data relating to nominality within the Methodist church}

It needs to be noted that several factors not discussed in this paper may also give rise to nominality, e.g. among others, the undermining of the laity (Stevens \& Collins 1996:139-142); unclear or lack of specific, concrete missional objectives (Callahan 1997a:1; 1997b:122-3); inadequate visitation by clergy and lay members (Callahan 1997a:11-22); irrelevant worship services and the inability to incorporate newcomers (Gibbs 1993: 73,76; Callahan 1997a:24ff); ineffective preaching and inappropriate evangelism (Gibbs 1993:71-3); inadequate small group ministry (Gibbs 1993: 75; Hudson 1995:77); and, too frequent changes of a minister (Gibbs 1993:77).

While each of these factors leading to nominality have an effect within the local church, this study seeks to rate the six identifiable marks of Christian discipleship as expanded from the Methodist Church's Laws and discipline (2000: 14-16): (1) regular worship; (2) regular fellowship by being a member of a small group or class meeting or cell; (3) commitment to service, outreach, mission and evangelism in the local community and (4) in the wider community; (5) generous giving and (6) studying and reading the Bible and praying.

Members were asked to rate from 1 to 6 which of these marks, when not given due attention, they considered the most important reason why Christians are not disciples. Members were then asked which of the same six marks when given proper attention would lead to the rediscovery of discipleship and assist Christians to be disciples.

In Tables 3A and 3B and in Tables 4A and 4B the data is averaged in two groups of those who rated the categories the value of 1 to 3 (most 
likely reasons) and those who rated the categories the values 4 to 6 (least likely reasons).

\subsection{Factors that prevent Christians from being disciples}

\section{Table 3: Analysis of data - causes leading to Christians not being disciples}

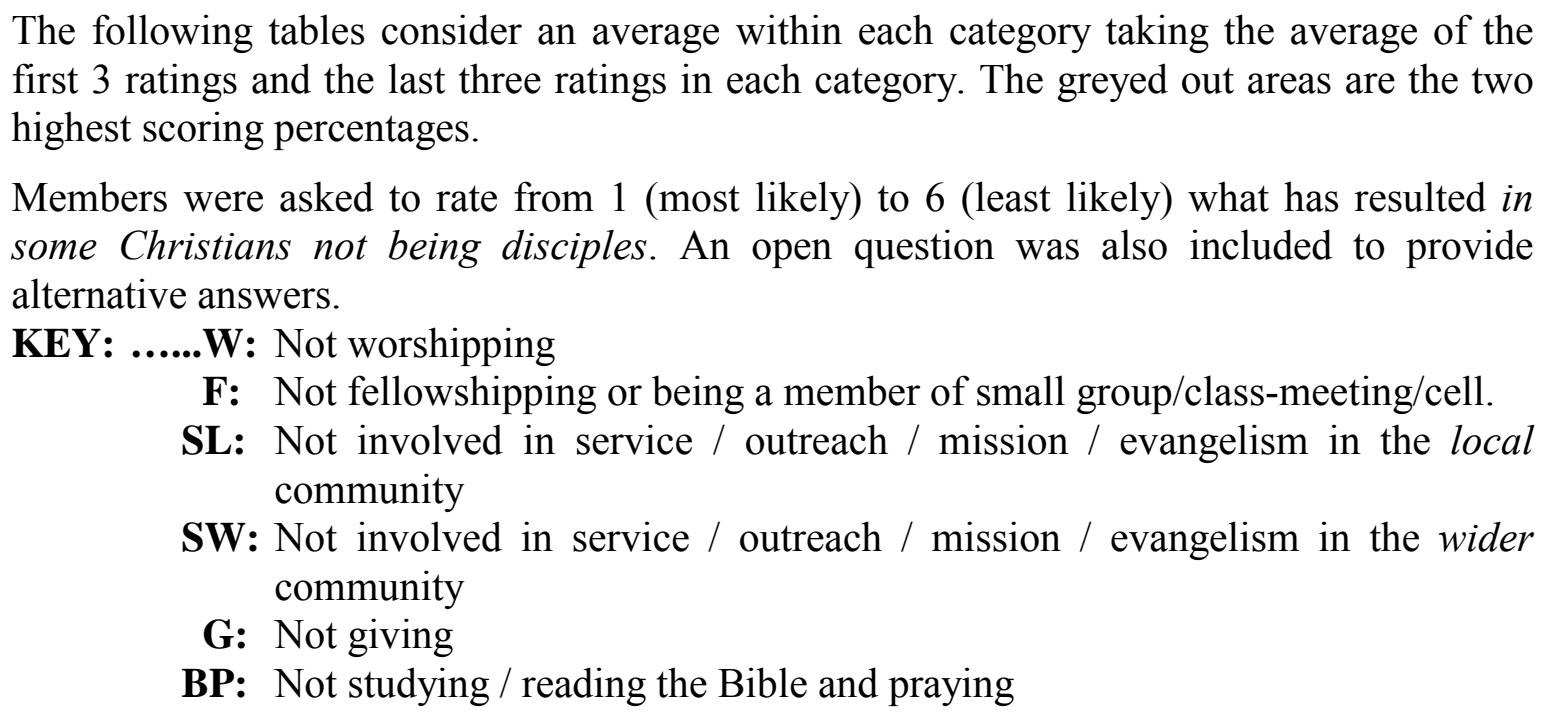

The following tables consider an average within each category taking the average of the first 3 ratings and the last three ratings in each category. The greyed out areas are the two highest scoring percentages.

Members were asked to rate from 1 (most likely) to 6 (least likely) what has resulted in some Christians not being disciples. An open question was also included to provide alternative answers.

KEY: ......W: Not worshipping

F: Not fellowshipping or being a member of small group/class-meeting/cell.

SL: Not involved in service / outreach / mission / evangelism in the local community

SW: Not involved in service / outreach / mission / evangelism in the wider community

G: Not giving

BP: Not studying / reading the Bible and praying

Note: percentages are calculated across the categories.

Table 3A: All questionnaires average in higher and lower group ratings

\begin{tabular}{|l|l|l|l|l|l|l|}
\hline Category: All Questionnaires & W & F & SL & SW & G & BP \\
\hline Rating 1-3 (most likely reasons) & $18 \%$ & $23 \%$ & $17 \%$ & $12 \%$ & $8 \%$ & $21 \%$ \\
\hline Rating 4-6 (least likely reasons) & $14 \%$ & $11 \%$ & $16 \%$ & $22 \%$ & $27 \%$ & $10 \%$ \\
\hline
\end{tabular}

Table 3B: Local Glen Methodist Church average in higher and lower group ratings

\begin{tabular}{|l|l|l|l|l|l|l|}
\hline Category: Local Church & W & F & SL & SW & G & BP \\
\hline Rating 1-3 (most likely reasons) & $19 \%$ & $21 \%$ & $17 \%$ & $12 \%$ & $9 \%$ & $22 \%$ \\
\hline Rating 4-6 (least likely reasons) & $12 \%$ & $13 \%$ & $16 \%$ & $23 \%$ & $27 \%$ & $9 \%$ \\
\hline
\end{tabular}

The two most rated contributing factors (cf. Table 3) for preventing Christians from being disciples (in both all the questionnaires completed and among local church members) were (a) members not fellowshipping in small groups (23\% and $21 \%$ respectively), and (b) not reading and studying the Bible and praying (21\% and $22 \%$ respectively).

In the open answers the following further reasons for Christians not being disciples were listed: lack of commitment; disobedience; unfaithful- 
ness; self-centredness; secular and rushed lifestyles, and incorrect priorities; disbelief; lack of mentorship and training; being put-off or disillusioned by other members or leaders or ministers in the church; not relying on God's grace; and, misunderstanding what it means to be a disciple.

\subsubsection{Factors that assist Christians to be disciples}

\section{Table 4: Analysis of data - factors helping Christians to be disciples}

The following tables consider an average within each category taking the average of the first 3 ratings and the last three ratings in each category. The greyed out areas are the two highest scoring percentages.

Members were asked to rate from 1 (most likely) to 6 (least likely) what has helped Christians to be disciples. An open question was also included to provide alternative answers.

Key: W: Regular worship

F: Regular fellowshipping by being a member of small group/class-meeting/cell.

SL: Commitment to service/outreach/mission/evangelism in the local community

SW: Commitment to service/outreach/mission/evangelism in the wider community

G: Generous giving

BP: Studying/reading the Bible and praying

Note: percentages are calculated across the categories.

Table 4A: All questionnaires average in higher and lower group ratings

\begin{tabular}{|l|l|l|l|l|l|l|}
\hline Category: All Questionnaires & W & F & SL & SW & G & BP \\
\hline Rating 1-3 (most likely reasons) & $19 \%$ & $23 \%$ & $15 \%$ & $13 \%$ & $9 \%$ & $21 \%$ \\
\hline Rating 4-6 (least likely reasons) & $12 \%$ & $10 \%$ & $19 \%$ & $23 \%$ & $28 \%$ & $9 \%$ \\
\hline
\end{tabular}

Table 4B: Local Glen Methodist Church average in higher and lower group ratings

\begin{tabular}{|l|l|l|l|l|l|l|}
\hline Category: Local Church & W & F & SL & SW & G & BP \\
\hline Rating 1-3 (most likely reasons) & $23 \%$ & $22 \%$ & $12 \%$ & $12 \%$ & $10 \%$ & $22 \%$ \\
\hline Rating 4-6 (least likely reasons) & $7 \%$ & $11 \%$ & $23 \%$ & $24 \%$ & $27 \%$ & $7 \%$ \\
\hline
\end{tabular}

The most rated contributing factors (cf. Table 4) of all the questionnaires and among the local church members for assisting Christians to be disciples were: (a) members fellowshipping (23\% and $22 \%$ respectively), and (b) reading and studying the Bible and praying $(21 \%$ and $22 \%$ respectively). In addition, the local church also indicated as the most 
contributing factor in assisting Christians to be disciples, (c) regular worship (23\%).

Regarding those elements that could assist Christians in being disciples the open questions revealed the following comments: need for commitment; need for constant encouragement; active involvement; being Christ-centred and not self-centred; being faithful; being disciplined and moral; attending the means of grace; attending training and equipping courses; and being accountable.

\section{CONCLUSIONS}

The study affirms the premise that there exists within the local church the difference of understanding of what it means to be "Christian" and a "disciple". The study highlights those factors that may assist in the building up of disciples.

As a follow up to this study it is important to ask the question of how the local church can implement these marks that encourage Christians to be disciples. How can the local church implement a process in which each and every member is challenged to worship and fellowship regularly, to commit themselves to service, outreach, mission and evangelism in the local community and in the wider community, to give generously and to grasp the importance of studying and reading the Bible and praying? How does the local church implement and encourage the need for commitment; the need for constant encouragement and active involvement; the need for assistance in being Christ-centred, faithful, disciplined and moral; the need to attend to the means of grace; the need to participate in training and equipping courses; and the need to allow members to be accountable to each other? While the obvious starting point would be from the pulpit, the place where the minister and leaders can share the vision to build up the local church, the actual process of building up of the church needs to extend beyond the limitations of the Sunday worship service.

It is suggested from the results of this study that such a "building ground" can be found within the small group ministry, i.e. in intimate fellowship, study and prayer. These are the key marks identified that when neglected lead to nominality, and when practiced enable the process of discipleship. This does not negate worship, service and giving, but it does indicate those areas in which Christians discern to be more effective in the process of discipleship. 


\section{Consulted literature}

Bonhoeffer, D 1988. The cost of discipleship. London: SCM Press.

Bosch, D J 1991. Transforming mission. Paradigm shifts in theology of mission. Maryknoll: Orbis Books.

Callahan, K L 1997a. Twelve keys to an effective church. Strategic planning for mission. San Francisco: Jossey-Bass Publishers.

-, 1997b. Twelve keys to an effective church. The leader's Guide. San Francisco: Jossey-Bass Publishers.

Gibbs, E 1993. Winning them back. Kent: Monarch Publications

Hudson, T 1995. Signposts to spirituality. Towards a closer walk with God. Cape Town: Struik Christian Books.

Methodist Church of Southern Africa. 2000. The laws and discipline of the Methodist Church of Southern Africa. Tenth edition. Salt River: The Methodist Publishing House.

Nel, M 1990. Building up the church. Theological perspectives. Pretoria: NG Kerkboekhandel.

(NRSV) The Holy Bible containing the Old and New Testaments. New revised standard version edited by B M Metzger... [et al.] 1989. Iowa Falls: World Bible Publishers, Inc.

Peterson, E H 1997. Saint Mark: The basic text for Christian Spirituality, in: Lyster, J Sharon, J and Santucci, P (eds.) Subversive Spirituality. Michigan: Grand Rapids, 3-15.

Shelley, B L 1982. Church history in plain language. Dallas: Word Publishing.

Stevens, R P \& Collins, P 1996. The equipping pastor. A systems approach to congregational leadership. New York City: The Alban Institute.

Watson, D 1983. Discipleship. London: Hodder and Stoughton.

Watson, D L 1990. God does not foreclose. The universal promise of salvation. Nashville: Abingdon Press.

Wesley, J 2000a. A plain account of Christian perfection as believed and taught by the Reverend Mr. John Wesley, from the year 1725, to the year 1777, in: The works of John Wesley: Addresses, essays, and letters. Electronic edition (Logos Library System [ON LINE]). Rio: Ages Software.

-, 2000b. The nature, design, and general rules of the united societies, in: The works of John Wesley: Addresses, essays, and letters. Electronic edition. (Logos Library System [ON LINE]). Rio: Ages Software.

-, 2000c. The works of John Wesley: Sermons. Sermons on several occasions. Electronic edition (Logos Library System [ON LINE]). Rio: Ages Software. 
Williams, C W 1988. John Wesley's theology today. A study of Wesleyan tradition in the light of current theological dialogue. Nashville: Abingdon Press. 